\title{
韓国における一社一村運動の展開要因と課題
}

\author{
張京花（神戸大学大学院国際文化学研究科） \\ 中塚 雅也（神戸大学自然科学系先端融合研究環） \\ 高田理（神戸大学大学院農学研究科）
}

\section{A Study on the Development and Problems of the “One Company, One Rural Village” Sisterhood Relationships in Korea}

\author{
Kyoung-Hwa Chang (Kobe University) \\ Masaya Nakatsuka (Kobe University) \\ Osamu Takada (Kobe University)
}

This study deals with recently expanded "One company, one rural village" sisterhood relationships in Korea, and reveals the actual conditions and problems through interviews and surveys.

A degree of effectiveness of the movement was seen under the mediated system of The National Agricultural Cooperative Federation (NACF), resulting in approximately 13,000 affiliated cases in three years. In addition, the estimated causes of the rapid expansion are attributed to high public empathy to support rural communities and active

\section{1. はじめに}

韓国の農村地域では，日本と同様，農産物市場開 放による農産物価格下落によって, 農業所得の減少, 若者の離農による過疎化，高齢化で農村地域の活力 が低下している。 そうした中，農山村地域を活性化 させるための方策として，一つの企業と一つの農村 が姉妹提携して, 農村体験や農産物直接取引, 相互 訪問などの活動を行ら一社一村運動が韓国全土に広 がっている. 一社一村運動は, 政策として実施され ていない「運動」にもかかわらず，急速に広がりを みせているが, その展開要因をはじめ, 実態や課題, 農村地域の活性化への寄与については, 不明な点が 多い、しかしながら，先行研究をみると，宮崎 [1] や浦出ら［2］によるマウル単位でのグリーンッー リズムに関する研究はあるものの，一社一村運動を 直接対象とした研究はほとんどない. promotion by NACF.

The issues for further expansion are (1) alleviation of the gap between the needs of the contractants, (2) quantitative and qualitative enrichment of programs, (3) frequent opinion exchanges and broad information sharing, and (4) strategic development for business activity, especially for corporations.

Despite the differences in social conditions, it is possible to develop the movement in Japan by carefully considering this study and the institutional arrangements.

本研究では，まず，一社一村運動の仕組久や展開 の実態を, 推進主体である韓国農協中央会の取り組 みとともに整理し, 韓国に扣ける運動展開の要因を 考察した，その上で，事例調査とアンケート調査を 実施し, 一社一村運動の効果と課題について分析し, 今後の継続的な発展の要件について考察した. また, 同じような運動は, 日本の静岡県でも行われており, 本研究による一社一村運動の発展要因と課題の解明 は，本運動を国際的な運動としていくための意義が あると考觉る。

調査は，韓国農協中央会に対する電話と対面によ る聞き取り調査（2007年 $8 \sim 11$ 月， 2008 年 7 月） に加光, 先進事例といわ机る $\mathrm{S}$ 社と $\mathrm{T}$ マウルの提携 の事例調查 (2007 年 8, 9 月), そして, 一社一村運 動に取り組む企業と農村（以下マウルと称する）, それぞれ 100 件を対象としたアンケート調查を打こ 
なった．有効回答数は，企業 $32 ，$ マウル 48 である.

\section{2. 一社一村運動の経緯と動向}

\section{（1）一社一村運動の背景}

韓国の農村（邑・面地域）人口は, 1970 年は 1,850 万人であったが，その後急速に減少し，2005 年に は876万人になっている。それにともない，韓国総 人口に占める農村人口の割合は 1970 年には $58.8 \%$ あったが, 2005 年には $18.5 \%$ にで減少した。 また， 農村人口に占める 65 歳以上者の割合は年々上昇し, 1970 年 $4.2 \%$ （都市 $2.1 \%$ ）であったが, 2005 年

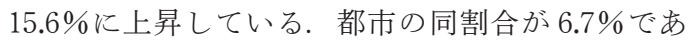
ることから，農村地域に打いて高齢化がいかに急速 に進行しているかがわかる。 また，1985 年には 20.2 万 ha であった耕作放棄地面積は，2005 年には 44.2 万 ha に増加している. これは農村の過疎化, 高齢化による労働力不足が大きな原因であると考兄 られる，以上のように韓国では, 農村地域の高齢化, 耕作放棄地の増加などによって，ますます農村地域 の活力が低下している. このよらな農村問題を克服 するため, 都市農村交流によって農村地域の活性化 が推進されてきた.

韓国では，ウルグアイラウンド交渉が始まった直 後の 1980 年代後半から身土不二運動が展開された. 「自分が暮す土地から生産された農産物が自分の体 と健康には最も良い」といら身土不二運動は, 国内 産農産物愛用運動として, 農協によって推進され, 短期間に国民的な運動として根を下ろした ${ }^{1)}$. その 後, 身土不二運動は, 農都不二運動として発展した. 農都不二運動とは「都市と農村, 消費者と生産者は ひとつになって助け合う」といら意味であり,「農 村と都市は一つ」といら共生の原理にもとづいた農 村愛の実践運動として農産物直接取引などの形態で 展開された ${ }^{2)}$ 。このような身土不二・農都不二運動 を推進していく過程で, 農協はスーパーであるハナ ロマートの開設や国産農産物を販売する「身土不二 空口」を設置するなどして, 都市地域での農産物販 売による交流を通じて農業・農村問題ついて全国民 の共感を得始めた。

さらに, 2004 年のチリとの FTA の発効, DDA（渡 河開発アジェンダ）の急進展などによってますます 農産物開放圧力が強まることから, 農業・農村の危 機感は非常に高くなってきた，そこで，この危機を
農民，消費者，政府が力を合わせて脱すべきである という機運が高まり，2004 年 6 月，全国経済人連 合会，農協中央会，文化日報が中心となって一社一 村運動を展開することになった。

\section{（2）一社一村運動の仕組みと動向}

一社一村運動とは，一つの企業が一つの農村を支 援しょらとする考光にもとづき，一つの企業が一つ の農村と姉妹提携を結び, 多様な交流活動を持続的 に行うことによって，コメなどの農産物開放で，苦 しくなった農業・農村を取り巻く環境を改善するた めに展開する運動である.

図 1 は, 一社一村姉妹提携の仕組みを示している. 一社一村運動は農協中央会内に農村愛汎国民運動本 部といら部署を設置し，一社一村運動に関する事業 を管轄している，運動本部は各地域の農協とのネッ トワークをもとに企業と農村の姉妹提携を締結して いる. 一社一村姉妹提携を希望する企業は, 申請書 に希望する村の位置, 規模, 村の特徵などを作成し, 農村愛沉国民運動本部または各地域の農協に申請す ると, 農協は企業が希望する条件に合う村を推薦し， 農協の斡旋によって姉妹提携が進められる.

一社一村運動の姉妹提携式は, 地域農協の主催で, 企業の役員と地域住民が参加して行われる. 当日の 食事費用の $50 \%$ 農協が支援する。ささらに，地域 農協は, 企業に姉妹交流や労働力支援, 農産物購入 に対しての感謝文，さらに年末のあいさつなど，年 計 4 回の書信を送っている ${ }^{3}$.

一社一村運動が開始された 2004 年開始時の提携 件数は 104 件であったが，わずか 3 年半後の 2006 年 12 月末には 12,975 件，つまり，韓国にある 4 万 余りのマウルの約 3 割が企業と姉妹提携した. な拈, 2007 年度からは実質的活動を扣こなっていない活 動不振提携 ${ }^{4)}$ が集計から除外されたため, やや減 少し, 2008 年 6 月現在では 7,700 件になっている.

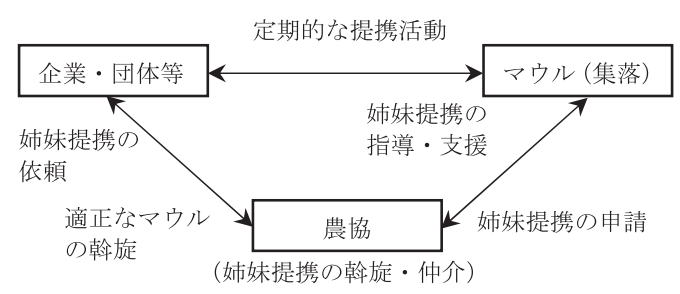

図 1. 一社一村姉妹提携の仕組み

資料：農村愛沉国民運動本部資料を基作成. 
一社一村運動に参加している 7,700 の企業・団体 を形態別にみると, 一番多いのは企業で 3,219 (41.8\% : 大手企業 6.8\%, 中小企業 $13.0 \%$, 政府投 資企業 8.8\%，その他 13.2\%)，次いで，官公署など 1,118（14.5\%)，農協なぞ $874(11.4 \%) ，$ 学校 576 (7.5\%)，消費者団体 457 (5.9\%), 社会・宗教団体 411 （5.3\%）と続いており，企業だけではなく学校， 消費者団体など社会を構成している多様な機関，団 体の参加がみら机る。

表 1 は, 韓国全体の農村地域に和任る一社一村運 動の実績を活動内容別にまとめたものである. 2006 年度の総交流件数は 47,594 件, 総交流金額は 901 億ウォンであった. 交流形態で件数, 金額ともに最 も多かったのは農産物直接取引で 492 億ウォン (54.6\%), 以下金額で多いのは, 労働力の援助が 158 億ウォン $(17.6 \%)$, 農村体験及び相互訪問が 91 億ウォン $(10.2 \%)$ となっている.

な打，農協中央会は，その推進のため大きな予 算を組んでいるが，特に広報に力を入れており， 各種テレビや新聞（文化日報，農協新聞等）で運 動の啓蒙と, 具体的な姉妹提携の活動紹介を抏こ なっている.

\section{表 1. 韓国の一社一村運動の実績（2006 年度）}

\begin{tabular}{|c|c|c|}
\hline 交流内容 & 件 数 & 金 額 \\
\hline 農産物直接取引 & $\begin{array}{c}11,943 \\
(25.1 \%)\end{array}$ & $\begin{array}{c}49,215 \\
(54.6 \%)\end{array}$ \\
\hline 労働力の援助 & $\begin{array}{c}11,364 \\
(23.9 \%)\end{array}$ & $\begin{array}{c}15,835 \\
(17.6 \%)\end{array}$ \\
\hline 農村体験及び相互訪問 & $\begin{array}{c}9,693 \\
(20.4 \%)\end{array}$ & $\begin{array}{c}9,148 \\
(10.2 \%)\end{array}$ \\
\hline $\begin{array}{l}\text { 寄贈品及びマウル発展基 } \\
\text { 金への寄付 }\end{array}$ & $\begin{array}{c}4,482 \\
(9.4 \%)\end{array}$ & $\begin{array}{c}5,031 \\
(5.6 \%)\end{array}$ \\
\hline $\begin{array}{l}\text { ボランティア及びマウル } \\
\text { の施設整備 }\end{array}$ & $\begin{array}{c}3,673 \\
(7.7 \%)\end{array}$ & $\begin{array}{l}4,515 \\
(5.0 \%)\end{array}$ \\
\hline 農協の資金支援 & $\begin{array}{c}438 \\
(0.9 \%)\end{array}$ & $\begin{array}{l}1,841 \\
(2.0 \%)\end{array}$ \\
\hline その他 & $\begin{array}{c}6,001 \\
(12.6 \%)\end{array}$ & $\begin{array}{l}4,491 \\
(5.0 \%)\end{array}$ \\
\hline 合 & $\begin{array}{l}47,594 \\
(100 \%)\end{array}$ & $\begin{array}{l}90,077 \\
(100 \%)\end{array}$ \\
\hline
\end{tabular}

資料：全国経済人連合会『1 社 1 村運動模範事例発表会集』 2007 年より作成.

\section{3. アンケート結果にみる運動の実態と評価 （1）企業の意向}

まず，回答 32 社の業種については，製造業が最も 多く $31.2 \%$, 次いでサービス $15.6 \%$, 宗教団体 9.4\%, 金融 9.4\%, 建築 $6.3 \%$, 電気 $3.1 \%$ ，その他 $25.0 \% て ゙$ あった。また，週 5 日勤務制度導入の有無は「有り」 が 61.5\%（1 ケ月当たり 4 回実施 $42.6 \% ， 1$ 个月当た り 2 回実施 18.9\%)，「無い」38.5\%であった.

図 2 は, 一社一村運動への取り組久の目的を尋祇 た結果である。「農業農村への理解とボランティア」 が 7 割を占めて扣り社会貢献活動としての意味合い が強いことがわかる。なお，別に，参加の契機を尋 ねた結果では，農協等の勧誘 $46.9 \%$ ，オーナ一の意 志 $37.5 \%$ が多く，マスメディアでの広報 $6.3 \%$ ，そ の他 9.4\%であった.

また，目的と対応して効果を尋衫たところ，「農 業農村への理解の向上」が $59.4 \%$ と最も多いが，次 いで，「安全な食材の購入しやすさ」28.1\%，「福利 厚生」 $6.3 \%$,「企業イメージ向上」3.1\%と続き, 目 的とは異なり，安全な食材購入チャネルをもつこと を効果として捉えていることが分かった．

また，現在の問題点については，「農村体験活動 に打故間の不足」が最も多く $37.5 \%$ ，次に「単 純かつ反復的な交流プログラム」 $21.9 \%$ ，「職員が 選好するマウルの施設の不足」 $15.6 \%$ ，「予算不足」 12.5\%の順になり，活動プログラム向上に関する課 題を抱えている.

\section{（2）マウルの意向}

図 3 は, マウルを対象に, 実際の活動内容を尋称 た結果である。「農産物直接取引」が最も多く, 次 いで「マウルの設備を利用した農村体験」となり「援 農・ボランティア」は高くはなかった。

図 4 は, 姉妹提携の効果について, 複数回答にて

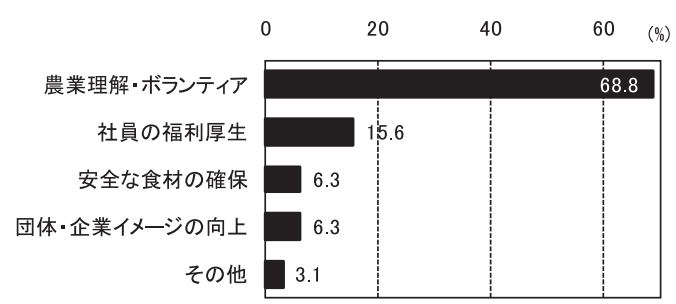

図 2. 企業等の姉妹提携締結の目的

資料：アンケート調査より作成. 


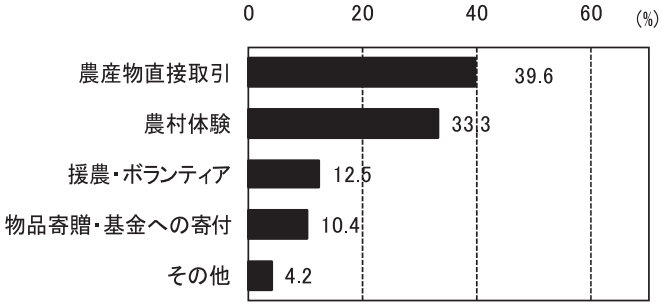

図 3. マウルでの活動内容（複数回答）

資料：アンケート調查より作成

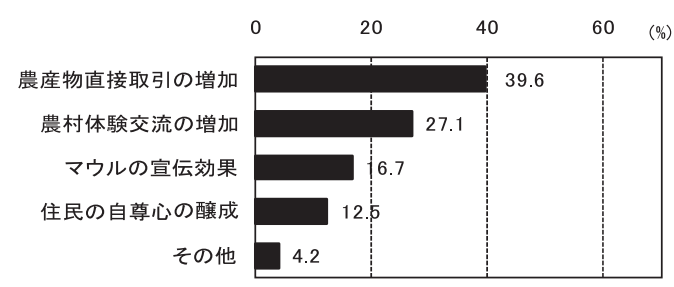

図 4. 姉妹提携の効果（複数回答）

資料：アンケート調査より作成.

尋祄た結果である。「農産物直接取引の増加」が最 も多く, 「農村体験交流の増加」と直接収入の増加 に繋がる項目への評価が高かった。また，注湆同じ 項目にて，今後の拡大を希望する活動を尋ねたとこ ろ, 同様に「農産物直接取引の増加」が $47.9 \%$ と最 も大きいが, 次いでは「援農などボランティア活動」 $29.2 \%$ ，「マウルの広報」 $12.5 \%$ ，「農村体験交流」 10.4\%と続き，マウルを人的にサポートする活動を 望む意向が伺えた。

\section{4. 姉妹提携の事例分析一 $\mathrm{T}$ マウルと $\mathrm{S}$ 社一}

\section{（1） T マウルと S 社の概要}

T マウル（集落）は，西に広州山脈があり，東に 太白山脈の険峻な支脈がつながっている所に位置 し, 江原道に属する. 人口は 398 人, 総世帯数は 82 戸，らち農家は 58 戸，非農家は 24 戸である。 専業農家は 30 戸で，第 1 種兼業農家は 17 戸，第 2 種兼業農家は 11 戸となっている。非農家は軍人家 族や公務員, 宗教人などである。経営耕地面積は 88 ha で，そのらち田は 53 ha，畑は 35 ha である. 高齢化が進んで拈り，60 歳以上の住民は約 $25 \%$ で ある。一部には，独居世帯も又られる。主要な農業 生産物は, 米, 唐辛子, ジャガイモ, カボチャ, 白 菜などである、マウルの共同施設として，マウル会 館 1 棟, 老人亭 1 棟, $\mathrm{T}$ マウル自然学校, 農機械保
管倉庫，精米所，宿泊施設，散策路がある.

一方， T マウルと姉妹提携している $\mathrm{S}$ 社は 1973 年に創立した大手電器企業で，2006 年度の売上高 は 2 兆 9,148 億ウォン, 総資産は 3 兆 1,257 億ウォン, 従業員数は国内事業所が 12,102 名, 海外事業所が 13,626 名で，総従業員 25,728 名，生産製品の $80 \%$ 以上を輸出している．S 社は社会貢献活動を第 5 の 経営資源として規定し，1995 年から S 社社会貢献 チームを組織し，企業の利益の社会への還元をす寸 めている。

\section{（2）姉妹提携の締結と活動内容}

$\mathrm{S}$ 社と $\mathrm{T}$ マウルの姉妹提携は, 2002 年に $\mathrm{S}$ 社の 週 5 日勤務制度の導入に拈いて ${ }^{5)}$ ，役職員抢よび家 族のリフレッシュ・プログラムを検討している際に, 農協江原道本部の仲介があったことが契機である。

$\mathrm{S}$ 社は姉妹提携を結ぶ時に，農村と企業が共生共 存できるよらな事業やアイディア創出及び提供を目 的とし，上下関係ではなく対等関係を形成し，農村 と企業が相互に必要とする提携を追求した。これは 一社一村運動の理念でもある.

$\mathrm{S}$ 社と $\mathrm{T}$ マウルの間で行われた主な事業は，親環 境農産物直接取引や農業・農村体験に上る交流, 援 農・ボランティア活動，寄贈なぞである。

まず，親環境農産物直接取引についてみると，S 社は，社内で $\mathrm{T} マ$ マアアルル米後援者を募集した． 初年の 2003 年には 58 人であったが，その後年々増 加して 2006 年には 250 人となっている。 また， $\mathrm{S}$ 社 は企業側が社内食堂で使ら食材として，Tマウルで

表 2. 2004 年度の提携活動

\begin{tabular}{l|l}
\hline \hline \multicolumn{1}{c|}{ 活動項目 } & \multicolumn{1}{|c}{ 具体的活動 } \\
\hline 農産物直接取引 & $\begin{array}{l}\text { アヒル米後援者 } 102 \text { 人 } \\
\text { 社員食堂用食材購入 月 } 3 \text { 回 }\end{array}$ \\
\hline 労働力の援助 & $\begin{array}{l}\text { ジャガイモや唐辛子などの収穫支援, } \\
\text { 約 } 2,000 人\end{array}$ \\
\hline $\begin{array}{l}\text { 農業農村体験及び } \\
\text { 相互訪問 }\end{array}$ & $\begin{array}{l}\text { ファームステイ, } 7 \text { 回 } \\
\text { 部署別ワークショップ, } 15 \text { 回 } \\
\text { 双方の行事参加, 4 回 }\end{array}$ \\
\hline $\begin{array}{l}\text { 寄贈品及びマウル } \\
\text { 発展基金への寄付 }\end{array}$ & アヒルのひな 6,000 羽寄贈 \\
\hline $\begin{array}{l}\text { ボランティア及び } \\
\text { マウルの施設整備 }\end{array}$ & 会館等の清掃, 12 回 \\
\hline
\end{tabular}

資料：聞き取り調査より作成. 
生産された米を 2003 年と 2004 年の 2 年間で 14 卜 ン（約 2,800万ウォン）を，2005 年からは毎年 16 トン（約 3,200 万ウォン）を購入している。また, 月 1 回は, 朝昼晚 3 食を $\mathrm{T}$ マウルの食材献立とす る日を設定している.

一方， $\mathrm{T}$ マウルでは， $\mathrm{S}$ 社との持続的かつ安定的 な親環境農産物の販路を維持するため, 2004 年度 から毎年 5 月の最後の土曜日を「S 社の日」とし， T マウルでは $\mathrm{S}$ 社の社員らとの交流機会を設けてい

る. 表 2 は, 2004 年度の 1 年間の交流事業を整理 したものである.

\section{（3）効果と課題}

姉妹提携による効果と課題について， T マウル， $\mathrm{S}$ 社それぞれの立場から整理する。

T マウルにとって, 最も大きな効果は, 農産物直 接取引と体験交流による農家所得の増大である. 持 続的かつ安定的な親環境農産物の販路を確保するこ とができた，Tマウルの 1999 年度における親環境 農産物販売高は 960 万ウォンであったが，提携後着 実に増加し 2004 年度は 5 億ウォンに達した。 それ にともない一戸当たり平均の農家所得も1999 年度 600 万ウォンから 2004 年度は 3,600 万ウォンに増加 した。 また, 体験・宿泊収入も 2001 年度 2,000 万ウォ ンから 2004 年度 1 億 5,000 万ウォンに増加した. また，援農についても，仮に単純に労働力換算をし た場合, 約 4,000 万ウォン相当の効果があったと考 えられる (4万ウォン (農村部日当たり労賃) $\times 2,000$ 人 (年間援農人数) $\div 2$ (半日) $)$. さらに, 加えて 留意すべきは広告効果である. 各種テレビ（韓国放 送局 1 回, $\mathrm{MBC} 1$ 回, SBS1 回）や新聞（文化日報, 農協新聞）で紹介されるなど，Tマウルの関係者ら は, 各種マスコミでの紹介による訪問客の増加を高 く評価している.

一方, $\mathrm{S}$ 社に打いては, 農業・農村への理解の深 まりの他に, 企業イメージの向上が最も大きな効果 として考えられている. S 社は, 一社一村運動優秀 企業として，2004 年度に農林部長官賞である「農 業人が選んだ今年の都市農村交流賞」を授賞した. このことは, 対内的にも, 社員の会社への愛着を高 める効果をもたらしている。 また, 社員に農業・農 村を理解させる効果に加え, 量として限定的とはい え, 親環境農産物を安定して購入するチャネルを確 保することを可能にした。
本事例の活動はこのように効果をあげているが， いくつかの課題も見られる。一つは, 活動内容と参 加者の固定化を避けるための活動プログラムの創出 である，当初の趣旨に示すように，相互のノウハウ と地域資源を活かしたプログラムの開発が求められ る.もら一つは, 活動の社員全体の活動としての展 開である. 現在は，アヒル米後援者キャンペーン6 の多くの後援者は $\mathrm{S}$ 社の役員に限定されて和り, 社 員全員への広がりが期待される。

\section{5. まとめ \\ （1）展開要因}

以上の結果をもとに，一社一村運動が短期間で韓 国全国に展開された要因について次の三点を示す.

第一に注目すべきは，急激に変化する韓国の社会 状勢である，通貨危機により経済のグローバル化が 更に推し進められるなか, 都市と農村の格差が短期 間のらちに広がり，国民感情として，農村の保全や 支援に対する共感がもたれている。 その背景には， 農村で生まれ育ち都市部へ移動した第一世代が社会 の中枢を占めていることも大きいと思われる.これ らが，企業等に求められ始めた CSR の取り組みと 関連づけられ，運動が広がったと考学られる。

第二の要因として挙げられるのは, 週 5 日勤務制 度の定着による余暇時間の増加である. 農村での体 験活動にあてることが可能な時間が増えたことの意 味は大きいと考觉られる。

第三の要因として取りあげるべきは，農協中央会 の活動支援事業であり，なかでも特に，仲介事業と 広報・啓蒙事業の充実である. 姉妹提携のマッチン グに沶いて，農協が果たす役割，主に斡旋・仲介は 大きい，また，広報は日常的に国民が目にするほど， 大規模に扣こなっている.

\section{(2) 効果と課題}

次に, 一社一村運動の効果と更なる発展への課題 について改めてまとめる.

まず効果としては，企業側は，（1）社員の福利厚 生の向上，(2）会社拉よび社員の安全な農産物の購 入チャネルの確立（3）企業イメージ向上とそれに伴 ら社員の会社へのコミットメント強化などがあげら れるまたマウル側にとっては，直接的には（1）提携 にともなら直接取引や交流事業による所得の増加, 間接的には (2) 紹介報道等による一般訪問客の増加, 
（3）外部者からの認知による地域への愛着と誇りの 形成といった心理的効果などがあげられる.

一方，臣とんど活動が行われていない姉妹提携も 確認されるなど, 今後の継続発展にはいつくかの課 題も考察される.

第一の課題は, 提携締結段階のミスマッチの解消 である. 提携締結に農協が果たす役割は大きいが, 仲介は書面だけの申請書に依存することも多いそ のため, 双方のニーズの整合性を充分に考慮されて ない恐れがある.それを避けるためには提携過程で 企業とマウルの話し合いが必要であるとともに，運 動への理解を深める教育の充実が求められる. 第二 に，提携活動の質量両面での充実である，提携関係 のなかでしか実現できない，双方の資源を活かし ニーズにあった活動プログラムを協動開発するこ と, また, 農村側に打いては, 直接取引に求められ る高品質農産物の生産をおこならことなどが重要で ある ${ }^{7)}$. そのためにも第三の課題として, 密な意見 交換と提携活動の広がりがあげられる. 広く情報を 共有することにより，会社内またはマウル内で一部 の人による活動となるのでなく, 全体的で多様な提 携活動が広がることが望まれる. 最後の課題は, 第 一の課題と関連するが, 企業が経営戦略的に姉妹提 携を捉えることである. 企業が事業領域外の社会貢 献活動としてだけでなく, 事業領域内での事業革新 や新たなビジネスの創出の機会として取り込む必要 がある. 特に中小規模の企業は今後, 継続が困難に なると思われる。

以上の課題等を改善することにより, 一社一村運 動は充実したものとなると思われる，また，社会的 状況が異なるとはいえ, 今後, 日本においてもさら に展開されることが望まれる。 その方策や条件整理 については今後の研究課題としたい.

注 1）韓国の身土不二運動について詳しくは文献 [3]を 参照.

2）「農都不二」への発展については文献 [4] を参照.
3）文献 [6] を参照.

4）交流不振の対象は，姉妹提携後 6 か月以上交流が ない場合, 企業体・団体従業員数 20 人未満の場合 （但し，交流が活発の場合は例外），交流金額が年 間 3 百万ウォン以下の場合，その他姉妹締結が不 適切と判断された姉妹締結である.

5）韓国では，2005 年 7 月 1 日より週 5 日勤務制度が 本格的に実施されている.

6） Tマウルのアヒル米栽培を応援するため, 役職員 が毎月 1 万ウォンの後援金を寄託し， S 社の日に 後援金相当のアヒルを寄託し，ここで栽培された 米を後援者，障害者施設，独居老人などに寄贈す る活動.

7）この点に関して，事例とした $\mathrm{T} マ$ ルでは先進的 に取り組んでいる，米の品質向上と住民の参加誘 因を高めるため, 自主的に米の等級を制定し，特 等級， 1 等級， 2 等級と分け，各等級に 9,000 ウォ ンずつの価格差を置いた．等級管理には外部の専 門者を招聘している.

\section{参考文献}

［1］宮崎 猛編『日本とアジアの農業・農村とグ リーンツーリズム』昭和堂, (2006).

[2]浦出俊和・宮崎猛「韓国に打けるグリーン ツーリズムの新展開一地域経営型グリーン ツーリズムの特徵と問題点一」, 『農林業問題 研究』第 41 巻第 1 号 (2005), pp.246-250.

[3] 全 相浩「国民に根ざす『身土不二』」, 『月刊 JA』557号 (2001).

[4]朴 昌緒『身土不二・農都不二』, 歓喜出版社, (1996).

[5]姜 信謙「農業・農村発展と企業の役割」,『CEO Information』，三星経済研究所 (2004).

［6］農村愛汎国民運動本部『都市と農村の姉妹提 携』，農協中央会農村支援部（2007）.

[7] 農協『農村愛 1 社 1 村』，農協中央会農村支援 部, (2006), p.10. 